NOTA TECNICA

\title{
Estandarización de la obtención de amplificados del genoma del virus de la rabia para su uso en estudios de epidemiología molecular
}

\author{
Andrés Páez, Clemencia García, Jorge Boshell \\ Laboratorio de Virología, Instituto Nacional de Salud, Bogotá, D.C., Colombia.
}

\begin{abstract}
Con el fin de perfeccionar el diagnóstico y la tipificación del virus de la rabia en Colombia, el Laboratorio Nacional de Referencia del Instituto Nacional de Salud estandarizó técnicas para amplificar un fragmento de ADN complementario (ADNc) a una fracción de 902 nucleótidos seleccionados del ARN del virus de la rabia. La fracción mencionada contiene secuencias que codifican para los aminoácidos 447-525 de la glicoproteína y 1-35 de la proteína L. Además, contiene la región intergénica no codificante conocida como Pseudogen Psi. Las técnicas estandarizadas consistieron en: 1) amplificación biológica mediante reaislamiento del virus en ratón ICR, 2) extracción del ARN total a partir del cerebro del ratón infectado, y 3) amplificación molecular utilizando la técnica de transcripción reversa y reacción en cadena de la polimerasa (RT-PCR) para obtener el ADNc. La muestra del estudio constó de 30 cepas de virus de rabia obtenidas originalmente de 30 caninos y tomadas del banco del Laboratorio de Virología. Por su simplicidad, la metodología descrita en este estudio presenta grandes ventajas sobre las técnicas descritas en anteriores estudios. La tecnología propuesta es un complemento preciso de las técnicas de diagnóstico de la rabia; además, se aplica a la identificación de relaciones filogenéticas de diversos aislamientos y, por ende, se utiliza en la identificación de las dinámicas de transmisión y difusión geográfica del virus rábico.
\end{abstract}

Palabras clave: virus rábico, epidemiología molecular.

\section{Standardization of rabies virus genome amplification for molecular epidemiology studies}

In order to improve the diagnosis and typification of rabies viruses at the Instituto Nacional de Salud National Reference Laboratory for rabies, we standardized techniques for the amplification of a 902 nucleotide DNA fragment, complementary to a selected region of the rabies virus genomic RNA. This region codes for a segment of both the glycoprotein and protein $L$, and contains the G-L intergenic noncoding region known as Pseudogen Psi. The standardized techniques included: 1 ) biological amplification of rabies viruses by intracerebral mouse inoculation; 2) total RNA extraction from the brains of infected mice, 3) RT-PCR amplification of a 902 nucleotide DNA fragment complementary to the selected RNA region. The study sample consisted of 30 rabies virus strains isolated from dogs and selected from the virus bank of the Virology Laboratory. Due to their simplicity the methods described have several advantages when compared to methods reported in previous papers. The technology proposed is a precise complement to rabies diagnosis techniques, and can be applied to the identification of phylogenetic relations among rabies isolates, and, therefore, it is also used to identify rabies transmission dynamics and geographical distribution.

Key words: rabies virus, molecular epidemiology.

$\overline{\text { Correspondencia: }}$

Andrés Páez

apaezm@hemagogus.ins.gov.co

Recibido: 17/10/01; aceptado: 22/02/02
La rabia es una zoonosis causada por virus neurotrópicos del género Lyssavirus, familia Rhabdoviridae (1). El virión rábico tiene forma de bala y mide aproximadamente $150 \mathrm{~nm}$ de largo por $80 \mathrm{~nm}$ de ancho. Contiene ARN de cadena 
sencilla y sentido negativo, compuesto por 12.000 nucleótidos, el cual codifica cinco proteínas estructurales (2).

Actualmente, la transmisión de los virus de la rabia representa una gran amenaza para la salud de la población colombiana. Durante el período 19922002 (hasta febrero) se registraron en el país 1.033 casos de rabia en perros y 42 en humanos. El $94 \%$ de estos casos se concentró en sólo tres regiones del país y el $6 \%$ restante se distribuyó en 15 departamentos $(3,4)$. Las tres regiones implicadas en la mayoría de casos incluyen el altiplano cundiboyacense, el departamento de Arauca y la región caribe colombiana (departamentos de Atlántico, Bolívar, Cesar, Córdoba, Magdalena y Sucre). La transmisión del virus de la rabia urbana (transmisión entre caninos y humanos) en el altiplano cundiboyacense y Arauca se controló en 1997, mientras que en la región Caribe sigue siendo un grave problema de salud pública, particularmente en los departamentos de Atlántico y Magdalena.

La Red Nacional de Laboratorios para el diagnóstico de la rabia en caninos, humanos y mascotas domésticas en Colombia está formada por siete laboratorios localizados en Arauca, Barranquilla, Bucaramanga, Cali, Cúcuta, Medellín y el Instituto Nacional de Salud en Bogotá que sirve de referencia nacional y, además, tiene como territorio de influencia a Cundinamarca, Huila, Tolima, la Orinoquia (Meta, Casanare, Arauca, Guainía y Vichada) y la Amazonia (Amazonas, Putumayo, Caquetá y Vaupés).

El presente artículo describe las técnicas moleculares de extracción del ARN total a partir de cerebros de ratones infectados con rabia, transcripción reversa y reacción en cadena de la polimerasa (RT-PCR), las cuales fueron estandarizadas para amplificar una región del genoma del virus de la rabia comprendida entre los nucleótidos 4665 al 5566, con 237 y 106 nucleótidos que codifican para los aminoácidos 447-525 de la glicoproteína y 1-35 de la proteína $\mathrm{L}$, respectivamente (5). Esta región contiene, además, la secuencia intergénica no codificante G-L de 559 nucleótidos mejor conocida como el Pseudogen Psi (5); es altamente variable y, por tanto, muy conveniente para realizar estudios epidemiológicos encaminados a fortalecer la vigilancia de la enfermedad y evaluar los programas de vacunación a nivel nacional.

\section{Materiales y métodos}

\section{Amplificación biológica mediante reaislamiento del virus rábico en ratón}

Esencialmente, se utilizó parte del procedimiento recomendado por la Organización Munidal de la Salud para el diagnóstico rutinario de la rabia (6). Después de seleccionar los virus para el estudio, se aislaron nuevamente de la siguiente manera: $1 \mathrm{~g}$ de cerebro infectado se maceró con $5 \mathrm{ml}$ de una solución de suero normal de caballo al $2 \%$, penicilina $100 \mathrm{Ul} / \mathrm{ml}$ y estreptomicina $100 \mu \mathrm{g} / \mathrm{ml}$. Una vez centrifugada la suspensión anterior durante 15 minutos a $8.000 \mathrm{~g}$ y temperatura ambiente, $30 \mu \mathrm{l}$ del sobrenadante se inocularon en ratones ICR blancos suizos, machos, de 21 días de edad y criados en el bioterio del Instituto Nacional de Salud en Bogotá. La inoculación se hizo en cabina de flujo laminar, por vía intracerebral, utilizando una jeringa de $1 \mathrm{cc}$ $26 \mathrm{G} 3 /{ }_{8}$ (Becton Dickinson \& Co.). Los ratones se observaron diariamente hasta la aparición de síntomas de rabia murina y se sacrificaron. Una vez extraidos, los cerebros se conservaron a $-80{ }^{\circ} \mathrm{C}$ hasta el momento de su utilización.

\section{Extracción de ARN a partir del cerebro infectado con el virus rábico}

Para la extracción del ARN del virus rábico, se adaptó la técnica del trizol descrita por la compañía Gibco BRL-Life Technologies para la utilización del producto Trizol LS Reagent Cat. No. 10296-028, con algunas modificaciones. Así, en un vial tipo Eppendorff de $1,5 \mathrm{ml}$ se mezclaron $750 \mu \mathrm{l}$ de Trizol Ls Reagent con $150 \mathrm{mg}$ de cerebro de ratón ICR infectado con virus rábico. La mezcla se sometió a vórtex fuerte durante un minuto y se incubó a temperatura ambiente durante 5 minutos. Posteriormente, se añadieron $300 \mu \mathrm{l}$ de cloroformo, se mezcló por agitación y se incubó durante 15 minutos a temperatura ambiente. La mezcla se centrifugó a $4^{\circ} \mathrm{C}$ y 12.000 g durante 15 minutos. La fase acuosa superior se transfirió a un vial aparte, el cual contenía $500 \mu \mathrm{l}$ de alcohol 
isopropílico. La mezcla anterior se agitó vigorosamente y se incubó durante 15 minutos a temperatura ambiente. La mezcla se centrifugó a $12.000 \mathrm{~g} \mathrm{y} 4{ }^{\circ} \mathrm{C}$ durante 15 minutos, después de lo cual se descartó el sobrenadante y se añadieron suavemente $500 \mu \mathrm{l}$ de etanol al $70 \%$ sobre el pellet sin mezclar. El vial se centrifugó a $12.000 \mathrm{~g} \mathrm{y} 4^{\circ} \mathrm{C}$ durante 5 minutos, después de lo cual se retiró la totalidad del sobrenadante y el pellet (que corresponde a ARN total de cerebro de ratón más $A R N$ rábico) se resuspendió en 50 $\mu \mathrm{l}$ de agua tratada con dietilpirocarbonato (DEPC) al $0,1 \%$. El ARN tratado de esta manera se almacenó (en algunos casos durante más de dos años) a $-20{ }^{\circ} \mathrm{C}$ hasta el momento de hacer la amplificación por RT-PCR.

\section{Iniciadores}

En el procedimiento de RT-PCR (descrito abajo), se utilizó el iniciador $\mathrm{G}(+)$ localizado entre los nucleótidos 4665 y 4687 del genoma, con sentido positivo, y secuencia 5' GACTTGGGTCTCCCAACTGGGG 3', y el iniciador L(-) localizado entre los nucleótidos 5543 y 5566 del genoma, con sentido negativo, y secuencia 5' CAAAGGAGAG TTGAGATTGTATC 3'. Los iniciadores $\mathrm{G}(+)$ y L(-) se han utilizado anteriormente en estudios de epidemiología molecular de rabia en Francia y Suráfrica $(7,8)$. La región que se amplifica tiene un tamaño de 902 nucleótidos y, dada su gran variabilidad genética, resulta muy conveniente para hacer estudios de epidemiología molecular de virus rábicos provenientes de lugares geográficos cercanos.

\section{Amplificación molecular de un fragmento de $A D N c$ con la técnica de RT-PCR}

Para la técnica de RT-PCR, se adaptaron con algunas modificaciones, las metodologías descritas por la compañía Gibco BRL-Life Technologies para la utilización de los productos M-MLV Reverse Transcriptase Cat. 28025-013 y Taq DNA Polymerase recombinant Cat. 10342-020. Así, se mezclaron $5 \mu$ de la preparación de ARN con $1 \mu$ de una preparación $25 \mu \mathrm{M}$ del iniciador $\mathrm{G}(+)$. La mezcla se calentó a $65^{\circ} \mathrm{C}$ durante 2 minutos en un baño de agua regulado por termostato y, luego, se dejó enfriar a temperatura ambiente. Posteriormente, se añadieron los siguientes componentes a la reacción para alcanzar un volumen final de $20 \mu \mathrm{l}: 1 \mu \mathrm{l}$ de agua $0,1 \%$ DEPC (SIGMA), $4 \mu$ de buffer $5 X$ de retrotranscripción (Gibco $\mathrm{BRL}$ ), $2 \mu \mathrm{l}$ de $\mathrm{MgCl}_{2} 25$ $\mathrm{mM}, 2 \mu \mathrm{l}$ de ditiotreitol (DTT) 0,1M, $4 \mu \mathrm{l}$ de una solución de deoxinucleótidos $\mathrm{A}, \mathrm{G}, \mathrm{T}, \mathrm{C}$, a una concentración de 2,5 mM, $1 \mu$ de transcriptasa reversa (Gibco BRL) a una concentración de 20 $U / \mu l$. La reacción de retrotranscripción se incubó a $42{ }^{\circ} \mathrm{C}$ durante 60 minutos, al final de los cuales se procedió a iniciar la reacción de PCR de la siguiente manera: se tomaron $2 \mu$ de la reacción de retrotranscripción y se añadieron los siguientes componentes para alcanzar un volumen final de $50 \mu \mathrm{l}: 34 \mu \mathrm{l}$ de agua con Depco 0 1\%, $5 \mu \mathrm{l}$ de buffer $10 X$ de PCR (Gibco BRL), $4 \mu$ de una solución de deoxynucleótidos $A, G, T, C$, a una concentración de 2,5 mM, $2 \mu \mathrm{l}$ de $25 \mu \mathrm{M}$ de iniciador $\mathrm{G}(+), 2 \mu \mathrm{l}$ de $25 \mu \mathrm{M}$ de iniciador $\mathrm{L}(-)$ y 1 $\mu l$ de 2,5 U/ $\mu$ l Taq Polimerasa (Gibco BRL). La reacción se sometió a 35 ciclos de temperatura, uno de los cuales se describe a continuación: $94{ }^{\circ} \mathrm{C}$ durante 30 segundos, $45^{\circ} \mathrm{C}$ durante 90 segundos, $50{ }^{\circ} \mathrm{C}$ durante 20 segundos y $72{ }^{\circ} \mathrm{C}$ durante 60 segundos. Al finalizar los 35 ciclos, se incubó la reacción a $72{ }^{\circ} \mathrm{C}$ durante 5 minutos. El producto de PCR se sometió a electroforesis en geles de $1 \%$ agarosa (Boehringer Manheim Cat. 100439) y el fragmento de 902 pares de bases se purificó a partir del gel utilizando el GFX PCR DNA y el Gel Band Purification Kit (Amersham Pharmacia Biotech), de acuerdo con las especificaciones de la compañía, para ser secuenciado posteriormente. Cuando fue necesario repetir el proceso de RT-PCR, se partió del ARN extraido inicialmente y que había sido almacenado a $-20{ }^{\circ} \mathrm{C}$ en agua tratada con dietilpirocarbonato (DEPC) al 0,1\%.

\section{Resultados}

En este estudio se realizaron los procesos de amplificación biológica, obtención de ARN viral y amplificación molecular de la región seleccionada del ARN en 30 cepas de virus de rabia urbana obtenidos originalmente de 30 caninos. Durante el proceso de amplificación biológica, los ratones infectados comenzaron a demostrar los primeros síntomas de rabia entre 8 y 14 días después de la inoculación. Aunque en este estudio no se 
determinaron las causas de las diferencias en la cinética de aparición de los síntomas, éstas se pueden deber a factores como la cepa viral, la dosis de virus inoculados, factores propios de cada ratón (estado de nutrición, estado anímico, nivel de estrés) o factores ambientales como humedad y temperatura del bioterio. Un diagrama de la región seleccionada en el ARN rábico y del fragmento de ADNc de 902 nucleótidos amplificado por RT-PCR se aprecia en la figura 1. Cada uno de los fragmentos amplificados contenía en promedio de $1 \mu \mathrm{g}$ de ADNc cuantificado espectrofotométricamente. El producto de la amplificación se aprecia en la figura 2, la cual corresponde a un gel de agarosa al $1 \%$ donde se aprecia una única banda de 902 nucleótidos.

\section{Discusión}

Durante la década pasada se desarrollaron nuevas técnicas moleculares que se convirtieron en sofisticadas herramientas que actualmente son utilizadas en estudios de epidemiología de numerosos agentes infecciosos (virus, bacterias y parásitos protozoarios). En la actualidad, la tecnología de la reacción en cadena de la polimerasa (PCR), se utiliza para amplificar regiones seleccionadas del genoma de organismos patógenos, las cuales posteriormente, al ser secuenciadas y analizadas, se pueden utilizar para la identificación exacta de determinada cepa, para definir sus relaciones con otras en circulación y para determinar el número de genotipos diferentes de cualquier patógeno que circule en una determinada área geográfica. Así, los programas de prevención y control pueden

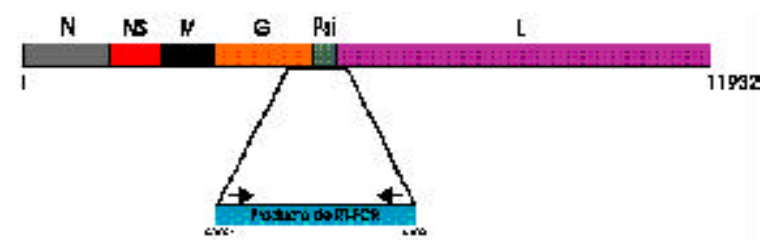

Figura 1. Representación del ARN genómico del virus de la rabia, en el cual los nucleótidos se muestran con números y con letras, los genes de la nucleoproteína $(\mathrm{N})$, fosfoproteína (NS), proteína de la matriz $(\mathrm{M})$, glicoproteína $(\mathrm{G})$, región intergénica no codificante o pseudogen psi (Psi) y la polimerasa $(\mathrm{L})$. La proyección en azul corresponde a la región del ARN que se amplificó por RT-PCR.

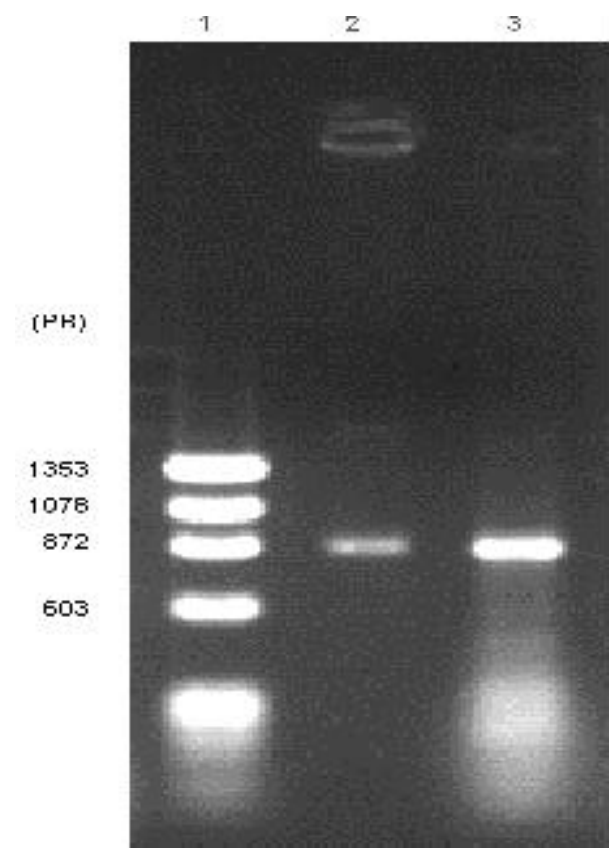

Figura 2. Gel de agarosa al $1 \%$ teñido con una solución de $0,5 \mu \mathrm{g} / \mathrm{ml}$ de bromuro de etidio, sobre el cual se realizó una electroforesis de los siguientes productos: 1) marcador de peso molecular OX174 DNA Hae III DIGEST (SIGMA); 2) fragmento de 902 pares de bases (PB) amplificado por RTPCR y pasado a través de una columna de purificación GFX DNA Purification Kit (PHARMACIA); 3) fragmento de 902 pares de bases amplificado por RT-PCR (sin purificar).

evaluarse, pues si ocurre una disminución en el tiempo del número de genotipos, se deduce que estos programas han sido efectivos y viceversa.

De esta forma, la expresión 'epidemiología molecular' ha ganado gran espacio dentro de los programas de investigación y vigilancia epidemiológica de numerosos patógenos (9-12). Se han realizado estudios de epidemiología molecular del virus de la rabia en diferentes países como Francia (7), Canadá (13), Suráfrica (8), Venezuela (14), Estados Unidos (15-17), Tailandia (18) e Israel (19). La estandarización de la metodología descrita en el presente artículo permite la realización de estudios de epidemiología molecular de la rabia en Colombia (documento en preparación), al lograrse la normalización de técnicas tales como la amplificación biológica de los aislamientos de virus de la rabia, la extracción de ARN total a partir de 
cerebros de ratones ICR infectados con rabia, la amplificación de un fragmento de ADN complementario a una determinada región del ARN genómico de los virus y la purificación del mismo. Con referencia a lo anterior, la metodología descrita en este estudio y, en particular, la descrita para la extracción de ARN presenta grandes ventajas sobre las técnicas descritas en anteriores estudios $(7,8)$. La técnica del trizol resulta mucho más fácil y directa que las ya descritas $(7,8)$, en las cuales se hace necesario la preparación y uso de un buffer compuesto por $1 \%$ SDS, $1 \%$ NP40 y $1 \mathrm{mM}$ EDTA, seguido por cuatro extracciones fenólicas. La región del ARN de los virus rábicos amplificada está comprendida entre los nucleótidos 4665 al 5566 del genoma y contiene 237 y 106 nucleótidos que codifican para los aminoácidos 447-525 de la glicoproteína y 1-35 de la proteína $L$, respectivamente. La región ha sido descrita como altamente variable, debido, en gran parte, a la presencia de la secuencia intergénica no codificante G-L de 559 nucleótidos, mejor conocida como el pseudogen psi (5), la cual acepta mutaciones al azar y, por tanto, es un buen indicador neutral de la evolución natural de los virus rábicos sin presión selectiva por parte del sistema inmune ni de ningún otro factor $(5,7)$. La región de 902 nucleótidos en mención se ha utilizado para estudiar las relaciones filogenéticas existentes entre virus que, a priori, se cree que se encuentran estrechamente relacionados $(7,8)$. El gen de la nucleoproteína es otra región del genoma rábico que ha sido ampliamente utilizada en estudios de epidemiología molecular en el mundo y que presenta una baja tasa de variabilidad, por lo cual se ha preferido para estudiar relaciones filogenéticas de virus aislados en regiones alejadas unas de otras o en países diferentes $(14,15)$.

\section{Agradecimientos}

El presente estudio fue realizado en el Laboratorio de Virología del Instituto Nacional de Salud de Bogotá, con el apoyo económico del Banco de la República de Colombia (contrato 200005), el Ministerio de Salud de Colombia (convenio 689 de 1999) y la Fundación Saldarriaga Concha (convenio 011-99 INS-SANUT).

\section{Referencias}

1. Meslin FX, Fishbein DB, Matter HC. Rationale and prospects for rabies elimination in developing countries. En. Rupprecht CE, Dietzschold B, Koprowski H, editors. Lyssaviruses. Berlin: Springer-Verlag; 1994. p.1-26.

2. Wunner WH, Larson JK, Dietzschold B, Smith CL. The molecular biology of rabies virus. Rev Infect Dis 1988;10:771-84.

3. Rico A, Díaz A, Rico E. Informe de la rabia urbana en Colombia, 1996-2001. Bogotá: Ministerio de Salud; 2001.

4. Instituto Nacional de Salud. Rabia. Quinta Edición. Bogotá: Instituto Nacional de Salud; 1995.

5. Tordo N, Poch O, Ermine A, Keith G, Rougeon F. Walking along the rabies genome: is the large $G-L$ intergenic region a remnant gene?. Proc Natl Acad Scien USA 1986;83:3914-8.

6. Koprowski H. Prueba de inoculación en ratones. En: Organización Mundial de la Salud. Técnicas de laboratorio aplicadas a la rabia. Washington, D.C.: OPS/OMS; 1956. p.57-69.

7. Sacramento D, Badrane $\mathbf{H}$, Bourhy $\mathbf{H}$, Tordo $\mathbf{N}$. Molecular epidemiology of rabies virus in France: comparison with vaccine strains. J Gen Virol 1992;73: 1149-58.

8. von Teichman BF, Thomson GR, Meredith CD, Nel LH. Molecular epidemiology of rabies virus in South Africa: evidence for two distinct virus groups. J Gen Virol 1995;76:73-82.

9. Tordo N. Contribution of molecular biology to vaccine development and molecular epidemiology of rabies disease. Mem Inst Butantan 1991;53:31-51.

10. McDade JE, Anderson BE. Molecular epidemiology: applications of nucleic acid amplification and sequence analysis. Epidemiol Rev 1996;18:90-7.

11. Gómez B, Cabrera L, Arias CF. Workshop on molecular epidemiology of viral diseases. Gac Med Mex 1997; 133(Suppl.1):63-8.

12. Hass L. Molecular epidemiology of animal virus diseases. Zentralbl Veterinarmed 1997;44:257-72.

13. Nadin-Davis S, Casey GA, Wandeler I. A molecular epidemiological study of rabies virus in central Ontario and western Quebec. J Gen Virol 1994;75:2575-83.

14. de Mattos C, de Mattos C, Smith JS, Miller ET, Papo S, Utrera A, et al. Genetic characterization of rabies field isolates from Venezuela. J Clin Microbiol 1996;34:1553-8.

15. Smith JS, Orciari LA, Yager PA, Seidel HD, Warner CK. Epidemiologic and historical relationships among 87 rabies virus isolates as determined by limited sequence analysis. J Infect Dis 1992;166:296-307.

16. Rohde RE, Neil SU, Clark KA, Smith JS. Molecular epidemiology of rabies epizootics in Texas. Clin Diagnos Virol 1997;8:209-17. 
17. Rupprecht CE, Smith JS, Krebs JW, Childs JE. Molecular epidemiology of rabies in the United States: reemergence of a classical neurotropic agent. J Neurovirol 1997;3(Suppl.1):s52-3.

18. Ito N, Sugiyama M, Oraveerakul K, Piyaviriyakul P, Lumlertdacha B, Arai YT, et al. Molecular epidemiology of rabies in Tailand. Microbiol Immunol 1999;43:551-9.

19. David T, Yakobson B, Smith JS, Starm Y. Molecular epidemiology of rabies virus isolates from Israel and other middle and near-eastern countries. J Clin Microbiol 2000; 38:755-62. 